\title{
IbM Kelompok Usaha Produk Olahan Susu Segar Di Dusun Boyong Desa Hargobinangun, Sleman Yogyakarta
}

\author{
Ninik Sri Rahayu*, Sri Indrawati** \\ *Dosen Diploma III FE UII \\ **Dosen Fak.TI,Prodi Teknik Industri UI \\ Email: ninik.srirahayu@uii.ac.id
}

\begin{abstract}
Micro, IBM's partner program (science and technology to the Community) are SMEs Heroine Boyong I (stick milk) and Heroine Boyong II (milk candy). Both are micro-scale industry based on fresh dairy product businesses.

IBM program on SME partners focused on the aspects of production and management. All activities in the production aspect functioned to improve the capacity and quality of production and increase dairy product variants. While aspects of management consists of: marketing, financial administration and human resource capacity building functioned as a partner in running the business well.

Outputs from the aspects of production activities are: lay out production in accordance with the concept of lean manufacturing, the addition of production capacity, increased efficiency of production of milk candy, increasing dairy product variants can be produced, the product is equipped with a production label and expiration date. In terms of management: managed to get a halal certificate from MUI, promotion of relevant equipment, attractive product design, wider marketing network, the use of social media for marketing, simple financial statements, bill of sale authorized, improved business mentality, and the ability of Partners in processing of fresh dairy products bertamba increased.
\end{abstract}

Keywords: SMEs, science and technology transfer, production and management

\section{PENDAHULUAN}

Dusun Boyong merupakan salah satu wilayah di kawasan lereng Merapi yang memiliki potensi lokal berupa produk susu segar. Hampir $90 \%$ masyarakat di wilayah ini memiliki peternakan sapi perah. Usaha peternakan menjadi penopang utama ekonomi masyarakat selain sektor pertanian. Dalam tingkatan rumah tangga, usaha tersebut dikelola bersama-sama antara suami dan istri. Pada umumnya terdapat pembagian kerja tradisional dimana para suami bertugas mencari pakan (rumput) sementara peran istri melakukan proses produksi (pemerahan) dan menjual ke koperasi terdekat. Nilai jual dari susu segar yang dihasilkan selama ini masih sangat rendah sehingga secara ekonomi kurang menguntungkan. Selain itu, produk olahan susu segar peternak lokal juga mentah belum dapat bersaing dengan susu segar yang dihasilkan oleh peternakan beskala besar.

Pasca erupsi Merapi, tepatnya pada awal tahun 2011 terbentuk dua kelompok usaha mikro yang memproduksi pangan berbahan baku susu segar yakni Srikandi 1 (memproduksi stik susu) dan Srikandi 2 (memproduksi permen susu). Usaha skala rumahan yang dikelola oleh kelompok perempuan ini memiliki perkembangan yang 
lambat baik dari sisi produksi maupun maupun manajemen usaha terkait dengan faktor terbatasnya sumber daya produktif yang dapat mereka akses. Riset yang dilakukan oleh Rahayu (2009) menyebutkan bahwa akses dan kontrol perempuan pelaku usaha mikro terhadap modal dan teknologi masih sangat terbatas, demikian juga terhadap sumber daya produktif yang bersifat non fisik/sosial seperti program pelatihan dan pendidikan. Isu gender juga tidak dapat dilepaskan dalam dinamika usaha ekonomi pinggiran yang dijalankan kaum perempuan ini. Dalam menggeluti usahanya, perempuan seringkali berhadapan dengan kendala yang dikenal dengan istilah "tripple burden of women", yaitu ketika mereka 'diminta' menjalankan fungsi reproduksi, produksi, sekaligus fungsi sosial di masyarakat pada saat yang bersamaan (Smeru,2003).

Lebih lanjut, Firdaus (2005) menyebutkan bahwa perempuan pengusaha mikro dalam menjalankan usahanya harus berhadapan dengan dua persoalan mendasar yaitu problem teknis usaha dan problem struktural. Dalam problem teknis usaha, perempuan pengusaha mikro mengalami hambatan yang tidak berbeda dengan laki-laki pengusaha mikro umumnya, seperti kekurangan modal, keterbatasan kontrol teknologi tepat guna, terbatasnya jaringan pasar, keterampilan manajemen, keterampilan teknis produksi dan kemampuan pengembangan desain. Problem krusial selanjutnya terletak pada problem struktural, dalam kondisi ini perempuan harus menghadapi dua persoalan sekaligus, Pertama adalah beragamnya kebijakan pemerintah seperti peraturan yang tidak adil mengenai sertifikasi kelayakan produk baik di pusat maupun daerah, peraturan kelembagaan seperti perbankan yang memberi layanan kredit serta ketidaksetaraan relasi dalam rantai produksi dan perdagangan. Kedua adalah hambatan yang berkaitan dengan "tubuh perempuan", yaitu perempuan sulit untuk pengembangan usahanya akibat adanya ketimpangan relasi gender. Ketimpangan relasi antara perempuan dengan keluarga dan suami baik di ranah domestik maupun di dalam masyarakat memunculkan hambatan serius bagi perkembangan bisnis yang mereka jalani. Berbagai hambatan tersebut berujung pada rendahnya akses dan kontrol perempuan terhadap berbagai sumber daya produktif seperti sumber permodalan, kredit, informasi pasar, bahan baku dan teknologi produksi sehingga kesempatan perempuan untuk mengembangkan usahanya menjadi terbatas.

Gambaran persoalan yang dihadapi oleh perempuan pengusaha mikro diatas juga dihadapi oleh UKM mitra IbM seperti terangkum dalam profil berikut ini :

Tabel 1 : Profil Aspek Usaha Mitra

\begin{tabular}{|l|l|l|}
\hline \multicolumn{1}{|c|}{ Aspek Bisnis } & \multicolumn{1}{|c|}{ Srikandi 1 } & \multicolumn{1}{c|}{ Srikandi 2 } \\
\hline Produk & \multicolumn{1}{|c|}{ Stick susu } & \multicolumn{1}{c|}{ Permen susu } \\
\hline $\begin{array}{l}\text { Omset } \\
\text { penjualan/ BIn }\end{array}$ & Rp. 300.000- Rp.500.000 & Rp.400.000-Rp.500.000 \\
\hline Lama usaha & 3 tahun & 3 tahun \\
\hline $\begin{array}{l}\text { Bahan Baku } \\
\text { produksi }\end{array}$ & $\begin{array}{l}\text { Bahan baku utama berupa susu } \\
\text { (millik sendiri), terigu, gula, garam, } \\
\text { telur dan minyak goreng. }\end{array}$ & $\begin{array}{l}\text { Bahan baku utama berupa susu } \\
\text { (milik sendiri), gula, garam, mentega. }\end{array}$ \\
\hline
\end{tabular}




\begin{tabular}{|c|c|c|}
\hline Produksi & $\begin{array}{l}\text { - } \begin{array}{l}\text { Produksi hanya dilakukan } \\
\text { berdasarkan }\end{array} \\
\text { dikerjakan di rumah salah satu } \\
\text { anggota kelompok. Rata-rata } 30- \\
50 \text { bungkus per bulan, dijual } \\
\text { seharga Rp10.000/bungkus. } \\
\text { - Produk sisa pemesanan } \\
\text { disimpan sebagai sampel di } \\
\text { rumah ketua kelompok. } \\
\text { Peralatan produksi yang dimiliki: } \\
2 \text { buah gilingan, blender, kompor } \\
\text { elpiji, wajan, spatula. Sebagian } \\
\text { merupakan bantuan dari PKM } \\
\text { UGM dan sebagian dari dana } \\
\text { sendiri. }\end{array}$ & 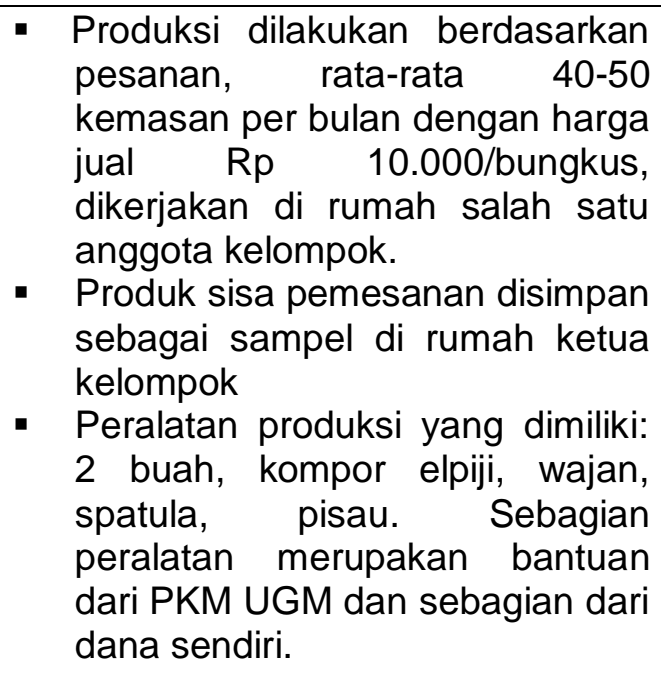 \\
\hline Manajemen & 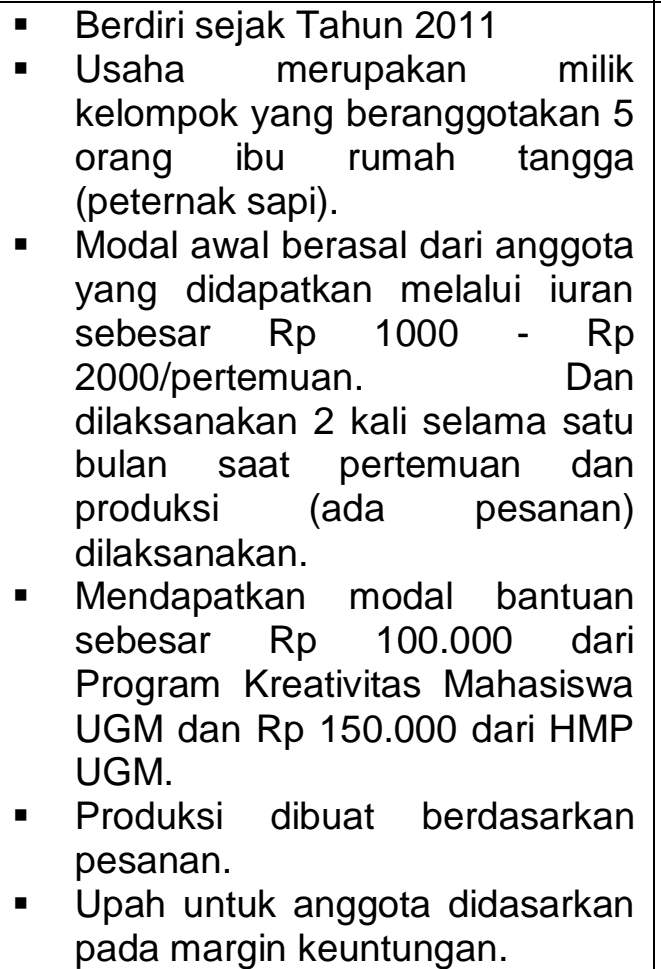 & 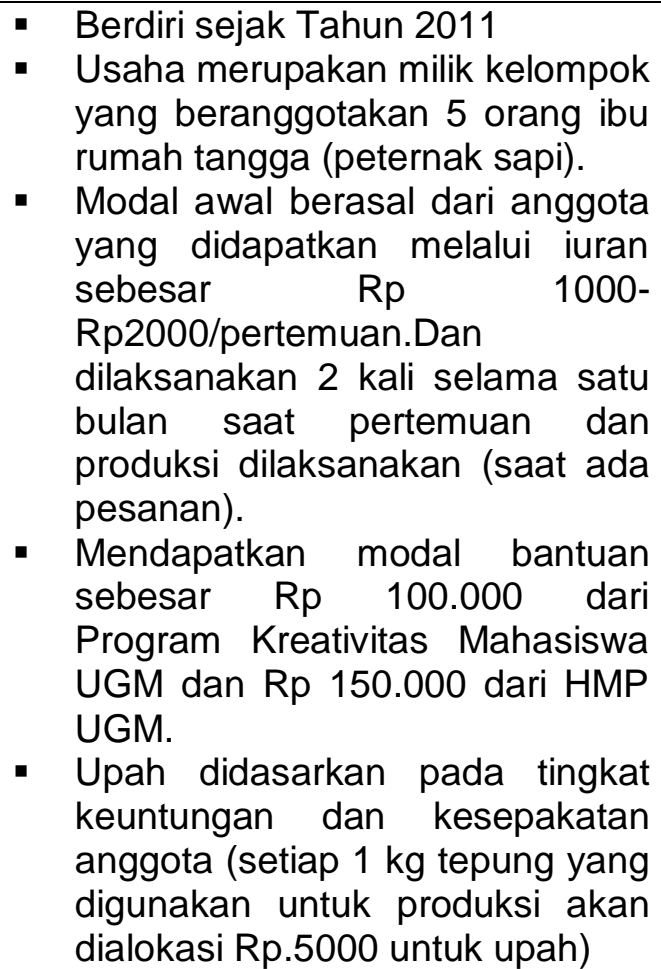 \\
\hline Pema & $\begin{array}{l}\text { Pemasaran yang dilakukan } \\
\text { masih berifat pasif, yakni dengan } \\
\text { menunggu konsumen datang } \\
\text { (pesanan). } \\
\text { - Mengikuti bazar kegiatan di } \\
\text { tingkat kecamatan, desa, hingga } \\
\text { kabupaten. } \\
\text { - Sampel produk dititipkan di } \\
\text { pusat oleh-oleh dan } \\
\text { DESPERINDAG }\end{array}$ & $\begin{array}{l}\text { - Pemasaran yang dilakukan masih } \\
\text { berifat pasif, menunggu } \\
\text { konsumen datang (pesanan) } \\
\text { - Mengikuti bazar kegiatan di } \\
\text { tingkat kecamatan, desa, hingga } \\
\text { kabupaten. } \\
\text { - Sampel produk dititipkan di pusat } \\
\text { oleh-oleh dan DESPERINDAG }\end{array}$ \\
\hline $\begin{array}{l}\text { Fasilitas } \\
\text { Komunika }\end{array}$ & HP dan Kartu Nama & HP dan Kartu Nama \\
\hline Finansial & 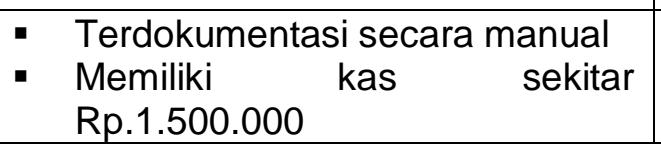 & $\begin{array}{l}\text { - Terdokumentasi secara manual } \\
\text { - Memiliki kas sekitar Rp } \\
2.000 .000,-\end{array}$ \\
\hline
\end{tabular}




\section{Permasalahan Mitra}

Tim pengusul bersama dengan mitra telah menyepakati persoalan prioritas untuk dapat diselesaikan dalam program IbM , yakni pada persoalan produksi dan manajemen usaha yang terangkum dalam tabel berikut ini :

Tabel 2 : Permasalahan Mitra

\begin{tabular}{|c|c|c|}
\hline Masalah/ Aspek & $\begin{array}{c}\text { UKM Mitra } 1 \\
\text { Srikandi } 1\end{array}$ & $\begin{array}{c}\text { UKM Mitra } 2 \\
\text { Srikandi } 2\end{array}$ \\
\hline Produksi & $\begin{array}{l}\text { - Belum memiliki ruang produksi } \\
\text { yang permanen } \\
\text { - Modal usaha terbatas, sehingga } \\
\text { produks hanya di lakukan } \\
\text { berdasarkan pesanan. } \\
\text { - Alat produksi (Cetakan) masih } \\
\text { manual dan sederhana sehingga } \\
\text { hasil produksi belum maksimal } \\
\text { - Belum memiliki izin produk usaha. } \\
\text { - Kelompok usaha memiliki } \\
\text { keinginan besar untuk } \\
\text { mengembangkan varian produk } \\
\text { berbahan baku susu segar tetapi } \\
\text { belum mempunyai keahlian. }\end{array}$ & 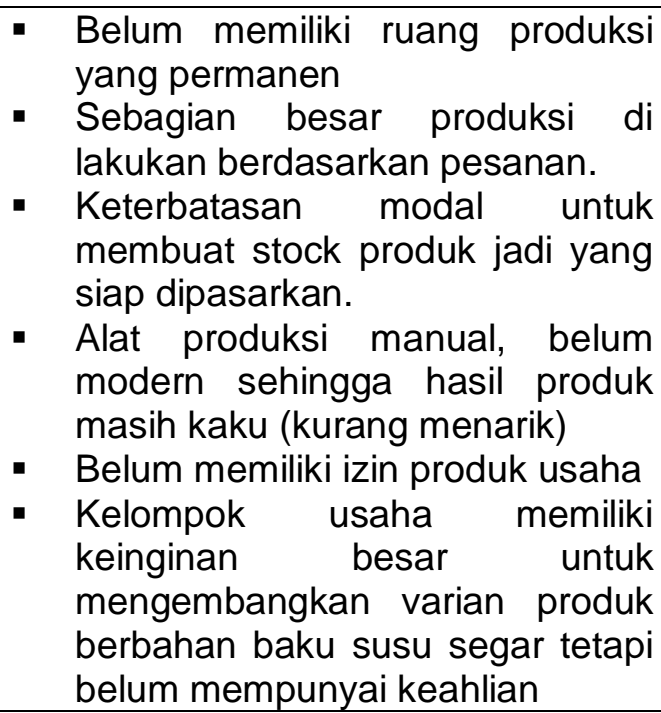 \\
\hline Manajemen & $\begin{array}{l}\text { - Promosi dengan mengikuti } \\
\text { pameran masih dilakukan secara } \\
\text { terbatas yaitu ketika ada pameran } \\
\text { gratis. } \\
\text { - Hasil produksi terkadang diberikan } \\
\text { secara cuma-cuma untuk sampel. } \\
\text { - Tidak memiliki gerai untuk } \\
\text { meyimpan hasil produksi } \\
\text { - Belum memaksimalkan } \\
\text { pemasaran dan promosi melalui } \\
\text { internet dan media elektronik } \\
\text { - Belum memiliki komputer } \\
\text { sebagai database pembuatan } \\
\text { laporan keuangan keuangan masih } \\
\text { - Pengelolaan keun } \\
\text { sangat sederhana, hanya sebatas } \\
\text { untuk mengetahui untung dan } \\
\text { rugi, belum ada informasi } \\
\text { mengenai jumlah aset yang } \\
\text { dimiliki. } \\
\text { - Penentuan harga jual hanya } \\
\text { berdasarkan biaya tenaga kerja } \\
\text { langsung dan bahan baku, belum } \\
\text { memperhitungkan biaya tidak } \\
\text { langsung. Tidak ada sistem akuntansi untuk } \\
\text { pencatatan laporan keuangan } \\
\text { - Jiwa wirausaha/entrepreneur } \\
\text { masih rendah sehingga minat }\end{array}$ & 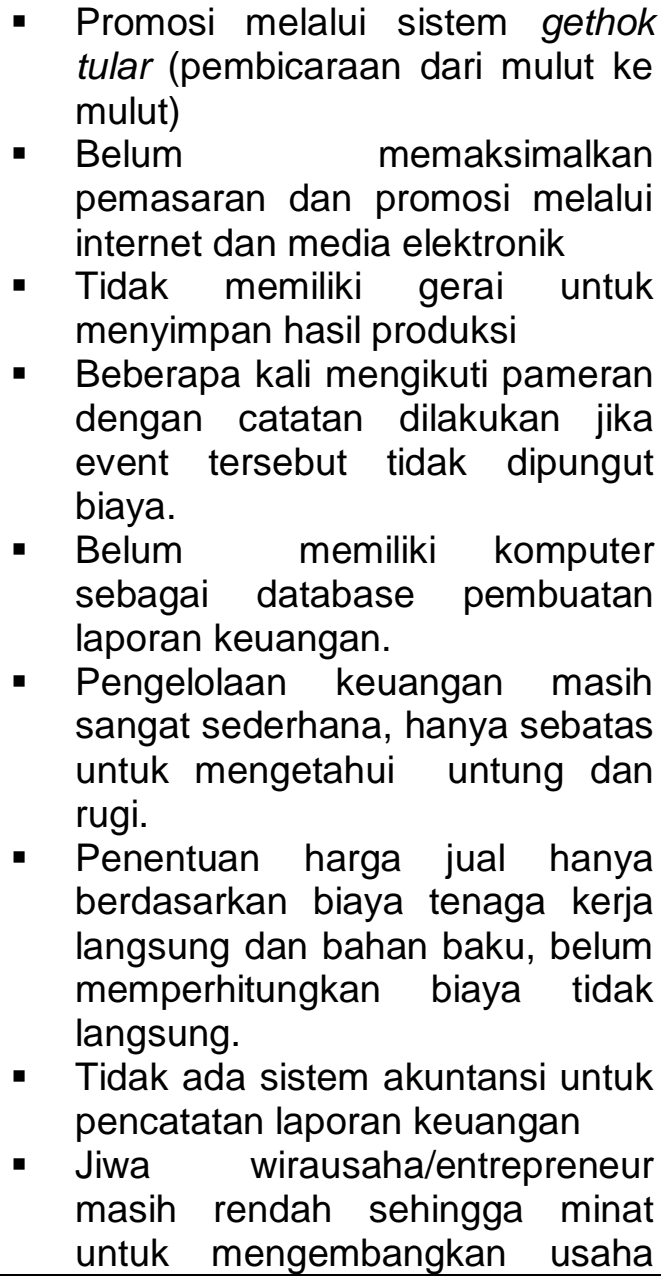 \\
\hline
\end{tabular}




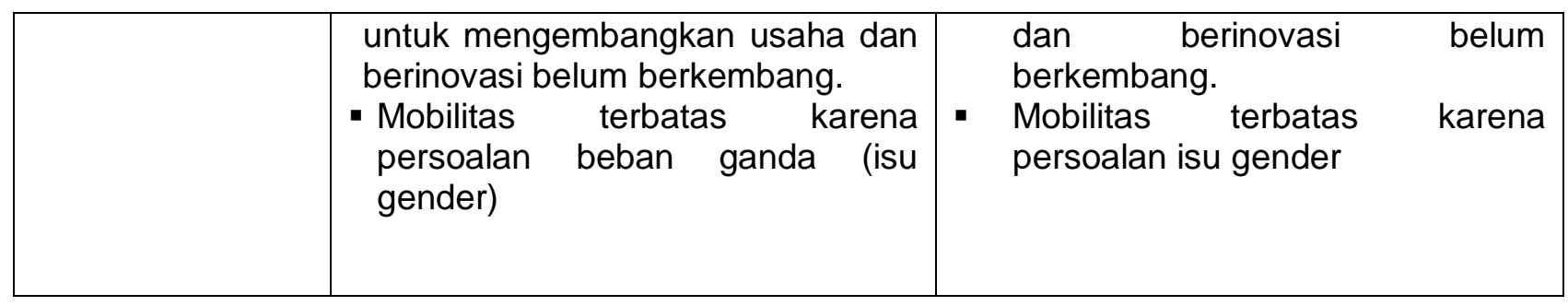

\section{Target dan Luaran}

Indikator yang digunakan untuk mengukur keberhasilan program IbM adalah sebagai berikut :

\section{Tabel 3 : Target Luaran Program IbM}

\begin{tabular}{|c|c|}
\hline Aspek & Target Luaran Program IbM \\
\hline Produk & $\begin{array}{l}\text { - Mitra } 1 \text { mampu menghasilkan varian produk berupa yogurt, keju dan } \\
\text { - Mabun susu yang berkualitas dan memenuhi selera pasar. } \\
\text { ditra } 2 \text { mampu menghasilkan varian produk berupa keju, yogurt dan } \\
\text { diversikasi rasa permen susu yang berkualitas dan memenuhi selera } \\
\text { pasar. } \\
\text { - Jumlah dan kualitas produksi meningkat. }\end{array}$ \\
\hline Manajer & $\begin{array}{l}\text { - Mitra mampu melakukan pemasaran menggunakan jejaring sosial } \\
\text { untuk meningkatkan pangsa pasar } \\
\text { - Mitra mampu membuat laporan keuangan secara sederhana } \\
\text { Keahlian dan ketrampilan Sumber Daya Manusia dalam proses } \\
\text { - } \text { Mroduksi meningkat. } \\
\text { - Ketivasi dan jiwa kewirausahaan mitra meningkat } \\
\text { (kesadaran gender meningkat) }\end{array}$ \\
\hline Paten (Ijin Usaha) & Masing-masing Mitra memiliki izin usaha pada produk yang dihasilkan. \\
\hline
\end{tabular}

Partisipasi Mitra (perempuan pengusaha mikro) menjadi kunci keberhasilan dalam seluruh kegiatan di atas. Sehingga diperlukan optimalisasi partisipasi dari Mitra. Partisipasi tersebut dapat berupa :

a. Keikutsertaan dalam kegiatan pelatihan.

b. Partisipasi dalam menyediakan dukungan tidak langsung terhadap pelaksanaan kegiatan, seperti tempat, perlengkapan, dan konsumsi.

c. Partisipasi pembiayaan untuk keberlanjutan program kegiatan ini.

\section{Metode Pelaksanaan}

Untuk menyelesaikan permasalahan UKM Srikandi Boyong 1 dan Srikandi Boyong 2, maka dalam Program lbM ini dilaksanakan beberapa kegiatan sebagai berikut:

\section{Srikandi I}

1. Aspek Produksi

Serangkaian program kegiatan yang dilakukan adalah sebagai berikut :
1) Memberikan bantuan alat produksi untuk menunjang kelancaran proses

produksi. Batuan alat produksi berupa panci stainless, spatula, dan mixer.

2) Melakukan Relay out ruang Produksi

3) Pelatihan diversifikasi produk

Selama ini UKM mitra hanya memproduksi stik susu sebagai produk unggulan. Keterbatasan ketrampilan untuk memproduksi produk lain berbasis susu menjadi salah satu kendala dalam mengembangkan usaha meskipun susu segar yang dihasilkan oleh UKM cukup banyak. Oleh karena itu, tim pengusul menyelenggarakan kegiatan pelatihan ( membuat yogurt dan sabun susu) untuk UKM mitra sebagai upaya meningkatkan ketrampilan teknis usaha. 
4) Pendampingan pengurusan izin produksi

Pengurusan izin usaha produk berbahan baku susu segar lebih rumit dibanding produk lain, mengingat susu merupakan produk yang sangat rentan terhadap kontaminasi bakteri. Sejauh ini UKM sudah berusaha mengajukan PIRT ke Dinas Kesehatan Sleman namun belum berhasil. Pada umumnya ijin produk susu hanya diberikan pada usaha dengan skala menengah dan besar sementara usaha yang ditekuni UKM masih berskala rumah tangga. Oleh karena itu tim merekomendasikan untuk mencantumkan SP (Sertifikat Pelatihan) pada produk yang dihasilkan.

2. Aspek Manajemen

1) Manajemen pemasaran

Pemasaran usaha selama ini masih bersifat pasif, menunggu pembeli ke rumah atau pesanan sehingga produksi setiap bulan fluktuatif. Saat ini tim sedang berusaha untuk membantu UKM mitra untuk memasarkan produknya ke toko oleh-oleh khas Yogyakarta di sekitar Jalan Kaliurang. Usaha lain yang dilakukan oleh tim adalah membuatkan logo usaha yang menyertakan alamat dan nomor kontak UKM untuk mempermudah calon konsumen yang akan melakukan pemesanan.

2) Administrasi keuangan

Administrasi keuangan belum tertata dengan baik selain itu arus keluar masuk kas juga tidak jelas sehingga sulit untuk mengetahui laba rugi usaha. Tim melakukan pendampingan pegelolaan administrasi keuangan untuk mendorong UKM mempunyai catatan administrasi keuangan yang baik.

3) Sumber Daya Manusia
Untuk meningkatkan wawasan SDM UKM, tim mengadakan kegiatan studi banding ke sentra pengolahan susu Cimory di daerah Ungaran, Jawa Tengah. Kegiatan ini bertujuan untuk memberikan referensi dan wawasan pada UKM utamanya mengenai packaging produk-produk berbahan susu, sistem pemasaran, lay out produksi dan pemasaran. Selain itu, program pelatihan diversifikasi produk yang dilakukan oleh tim juga bertujuan untuk meningkatkan keahlian dan ketrampilan SDM UKM mitra. Tujuan terpenting dari program ini adalah untuk menumbuhkan motivasi dan semangat kewirausahaan UKM, hal ini penting sebagaimana diakui oleh ketua kelompok Srikandi 1 bahwa semangat dan konsistensi para anggota untuk meneruskan usaha terkadang mengalami fase pasang surut dikarenakan persoalan ketidakpastian usaha.

\section{Srikandi II}

Persoalan yang dihadapi oleh Srikandi II relatif sama dengan UKM Srikandi I, sehingga tahapan penyelesaian yang dilakukan oleh tim juga tidak jauh berbeda.

\section{Aspek Produksi}

Untuk menyelesaikan persoalan produksi yang dihadapi oleh mitra, tim pengusul melakukan serangkaian kegiatan sebagai berikut :

1) Memberikan bantuan berbagai alat produksi untuk menunjang kelancaran proses produksi.

2) Melakukan Relay out ruang Produksi dengan mengacu pada prinsip $5 \mathrm{R}$ yakni ; Rapi, Ringkes, Resik, Rawat, sehingga ruang usaha menjadi lebih representatif

3) Pelatihan diversifikasi produk (pelatihan membuat yogurt dan keju). Produksi utama dari UKM Srikadi II adalah permen susu dengan varian rasa kacang, jahe dan original. Tim pengusul menyelenggarakan kegiatan 
pelatihan peningkatan ketrampilan teknis usaha berupa pelatihan membuat yogurt dan keju.

4) Pendampingan pengurusan izin produksi

Persoalan sulitnya mengurus izin usaha produk berbahan baku susu juga dialami oleh UKM Srikandi II, pengajuan PIRT ke Dinas Kesehatan Sleman namun belum mendapat respon. Sebagai alternatif, tim merekomendasikan untuk mencantumkan SP (Sertifikat Pelatihan) pada produk yang dihasilkan sembari menunggu proses pengurusan PIRT.

3. Aspek Manajemen

1) Manajemen pemasaran

Sistem pemasaran permen susu juga masih bersifat pasif, hanya menunggu pembeli ke rumah atau pesanan. Saat ini tim sedang berusaha untuk membantu UKM mitra untuk memasarkan produknya ke toko oleholeh khas Yogyakarta di sekitar Jalan Kaliurang. Usaha lain yang dilakukan oleh tim adalah membuatkan logo usaha yang menyertakan alamat dan nomor kontak UKM untuk mempermudah calon konsumen yang akan melakukan pemesanan.

2) Administrasi keuangan

Administrasi keuangan di Srikandi II juga belum tertata dengan baik, sehingga sulit untuk mengetahui laba rugi usaha. Tim melakukan pendampingan pegelolaan administrasi keuangan untuk mendorong UKM mempunyai catatan administrasi keuangan yang baik.

3) Sumber Daya Manusia Untuk meningkatkan wawasan SDM UKM, tim mengadakan kegiatan studi banding ke sentra pengolahan susu Cimory di daerah Ungaran, Jawa Tengah. Kegiatan ini bertujuan untuk memberikan referensi dan wawasan pada UKM utamanya mengenai packaging produk-produk berbahan susu, sistem pemasaran, lay out produksi dan pemasaran. Selain itu, program pelatihan diversifikasi produk yang dilakukan oleh tim juga bertujuan untuk meningkatkan keahlian dan ketrampilan SDM UKM mitra.

\section{Hasil Yang Dicapai}

UKM yang menjadi mitra IbM adalah Srikandi I (memproduksi stik susu) dan Srikandi II (memproduksi permen susu) yang berlokasi di Dusun Boyong, Hargobinangun, Sleman. Sepanjang satu setengah tahun terakhir, persoalan yang dihadapi kedua UKM berbasis susu segar relatif sama. Meskipun usaha telah dirintis sejak tiga tahun terahir (2011), perkembangan usaha relatif lambat, bahkan dalam beberapa aspek justru memperlihatkan gejala penurunan.

Anggota masing-masing kelompok mengalami pengurangan, jika pada tahun sebelumnya tiap UKM beraggotakan tiga orang ibu-ibu, saat ini baik UKM Srikandi I dan Srikandi Boyong II hanya memiliki anggota sebanyak dua orang. Hal tersebut disebabkan oleh sifat usaha yang belum memiliki order yang stabil. Sehingga pendapatan usaha untuk masing-masing anggota UKM yang masih rendah anggota. Namun persolan yang lebih serius sebenarnya adalah persoalan mentalitas usaha. Sulitnya mengembangkan, memasarkan, dan mengelola usaha menjadi alasan untuk tidak meneruskan aktifitas ekonomi tersebut. Produksi dari kedua UKM bersifat fluktuatif, produksi cukup banyak hanya pada musim tertentu seperti hari raya dan liburan. Namun pada hari biasa, produksi hanya untuk stok, melayani pembelian di rumah atau pesanan.

Tim IbM berupaya untuk melakukan transfer iptek pada UKM mitra sebagai solusi atas permasalah usaha yang dihadapai sebagaimana tergambar dalam skema berikut 


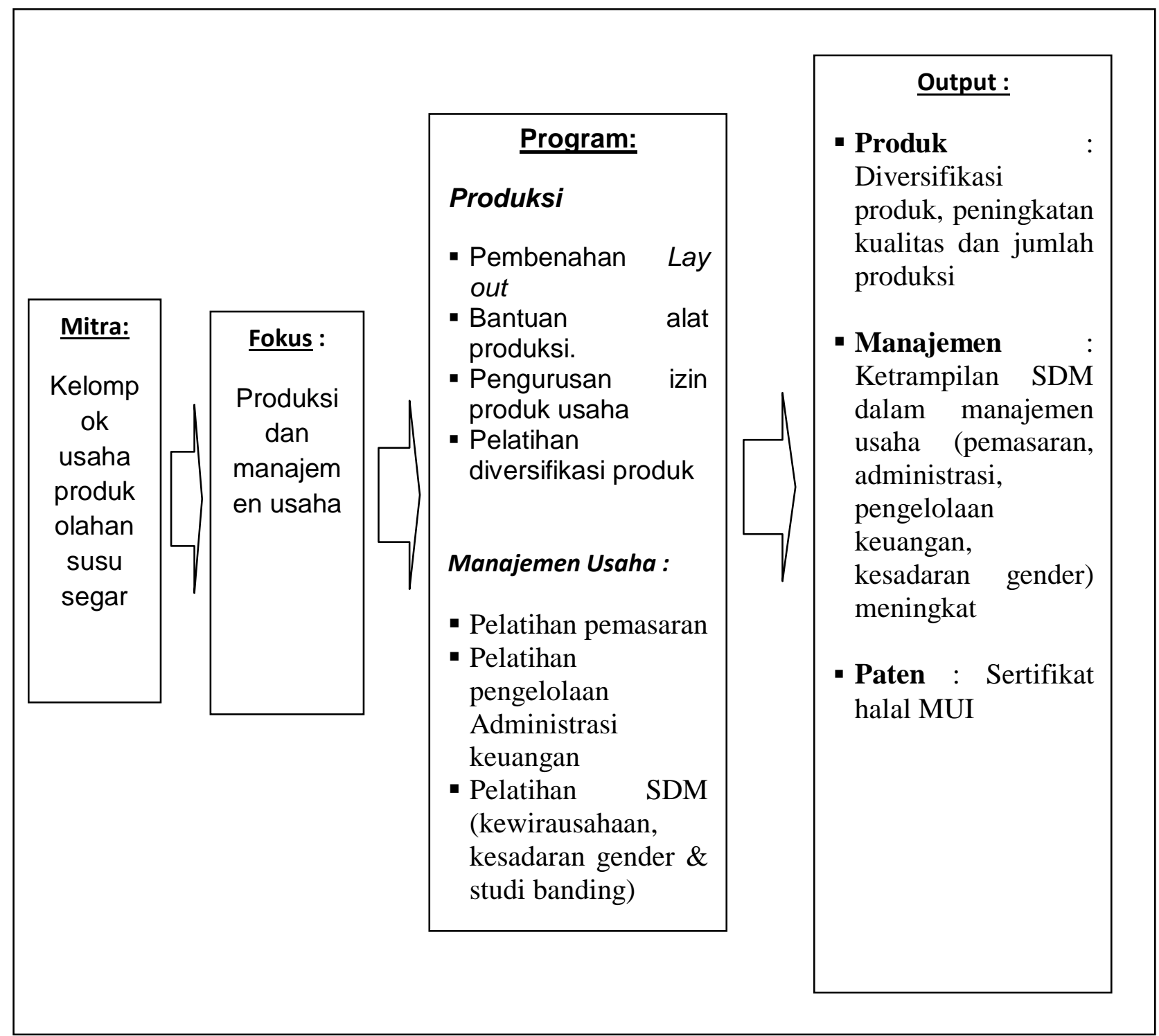

Tabel 5 : Hasil Yang Dicapai

\begin{tabular}{|c|c|c|}
\hline Aspek & Kegiatan yang dilakukan & Hasil \\
\hline Produksi & $\begin{array}{l}\text { - Dilakukan pembenahan layout agar } \\
\text { lebih representatif dengan prinsip } 5 \mathrm{~S} \\
\text { (Kerjasama dengan Lab. Sistem } \\
\text { Manufaktur FTI UII). } \\
\text { - Memberikan bantuan alat produksi } \\
\text { untuk meningkatkan kapasitas } \\
\text { produksi. }\end{array}$ & $\begin{array}{l}\text { - Layout produksi yang sesuai dengan } \\
\text { konsep lean manufacturing dengan } \\
\text { pendekatan } 5 \mathrm{~S} \text { (Kerjasama dengan } \\
\text { Lab. Sistem Manufaktur FTI UII). } \\
\text { - Penambahan kapasitas produksi } \\
\text { melalui pemberian peralatan: mixer, } \\
\text { blender, spatula, kompor gas \& } \\
\text { tabung, panci stainless, spatula, } \\
\text { blender, kompor gas, tabung gas, } \\
\text { dan perlengkapan lain untuk } \\
\text { membuat keju seperti toples, } \\
\text { breaker glass } 200 \mathrm{ml} \text {, pyrex, botol }\end{array}$ \\
\hline
\end{tabular}




\begin{tabular}{|c|c|c|}
\hline & $\begin{array}{l}\text { - Mengidentifikasi peralatan produksi } \\
\text { yang dibutuhkan untuk melakukan } \\
\text { diversivikasi produk dengan } \\
\text { berkonsultasi pada pakar pengolahan } \\
\text { susu dari Fakultas Teknologi } \\
\text { Pertanian UGM. } \\
\text { - Melakukan pemesanan stempel } \\
\text { production dan expired date. } \\
\text { - Melaksanakan pelatihan diversifikasi } \\
\text { produk (keju, yogurt \&sabun susu) } \\
\text { oleh tim pakar dari Fakultas Teknologi } \\
\text { Pertanian UGM. } \\
\text { - Memiliki sertifikat halal MUI }\end{array}$ & $\begin{array}{l}\text { derigen, ember besar, alumunium } \\
\text { foil, stok pot orc tbl, measuring } \\
\text { cup super, baki plastik, pipet } \\
\text { tetes, dan termometer. } \\
\text { - Meningkatnya efisiensi produksi } \\
\text { permen susu. } \\
\text { - Bertambahnya varian produk susu } \\
\text { yang dapat diproduksi dengan } \\
\text { bantuan peralatan seperti: kompor } \\
\text { gas, timbangan roti, thermometer, } \\
\text { panci dan pengaduk, toples dan } \\
\text { lainnya. } \\
\text { - Produk sudah dilengkapi dengan } \\
\text { label production dan expired date. } \\
\text { - Bertambahnya jumlah varian produk. } \\
\text { - Memilliki sertifikat halal MUl }\end{array}$ \\
\hline Manajemen & $\begin{array}{l}\text { Pemasaran : } \\
\text { - Menyiapkan desain leaflet, } \\
\text { stiker/label produksi dan kartu nama } \\
\text { untuk UKM. } \\
\text { - Mendesain ulang kemasan masing- } \\
\text { masing produk dengan desain yang } \\
\text { lebih menarik. } \\
\text { - Membantu pemasaran produk } \\
\text { melalui jaringan yang dimiliki oleh } \\
\text { tim (kolega, kerabat, keluarga) } \\
\text { - Membangun jaringan dengan } \\
\text { Deperindagkop, Sleman pan pakngan } \\
\text { - Membangun networking dengan } \\
\text { institusi pendidikan (Fakultas } \\
\text { Teknologi Pertanian UGM). } \\
\text { - Melakukan pelatihan pemasaran } \\
\text { produk melalui jejaring sosial. } \\
\text { Administrasi Keuangan: } \\
\text { - Melakukan pelatihan manajemen } \\
\text { keuangan sederhana. } \\
\text { - Pemesanan Nota penjualan } \\
\text { SDM } \\
\text { - Melakukan pelatihan kewirausahaan } \\
\text { dengan mendatangkan entrepreuner } \\
\text { dalam bidang usaha pengolahan } \\
\text { produk berbahan baku susu. } \\
\text { - Studi banding ke sentra produk } \\
\text { berbahan baku susu segar di Cimory } \\
\text { Ungaran produk (keju,yogurt dan sabun susu } \\
\text { oleh tim dari fakultas Tek.Pertanian } \\
\text { UGM ). }\end{array}$ & $\begin{array}{l}\text { Pemasaran: } \\
\text { Mitra memiliki peralatan promosi } \\
\text { yang relevan seperti: leaflet, stiker, } \\
\text { kartu nama untuk UKM. } \\
\text { - Produk memiliki desain yang lebih } \\
\text { menarik. } \\
\text { - Meluasnya jaringan pemasaran } \\
\text { Mitra. } \\
\text { - Meluasnya jaringan pemasaran } \\
\text { Mitra. } \\
\text { Adanya link kerjasama dengan } \\
\text { institusi pendidikan (Fakultas } \\
\text { Teknologi Pertanian UGM). } \\
\text { - Meningkatnya kemampuan } \\
\text { pemasaran Mitra. } \\
\text { Administrasi Keuangan: } \\
\text { - Mitra dapat membuat laporan } \\
\text { keuangan sederhana. } \\
\text { - Mitra memiliki nota penjualan dengan } \\
\text { logo UKM nya. } \\
\text { SDM Meningkatmya mentalitas usaha } \\
\text { - Magi pelaku UKM. } \\
\text { Meningkatnya wawasan UKM } \\
\text { tentang diversivikasi produk olahan } \\
\text { susu dan membuka link kerjasama } \\
\text { dengan pabrik cimory. } \\
\text { Meningkatnya kemampuan Mitra } \\
\text { dalam pengolahan susu menjadi } \\
\text { berbagai varian produk. }\end{array}$ \\
\hline
\end{tabular}




\section{Kesimpulan dan Saran \\ Kesimpulan}

Program Ipteks Bagi Masyarakat untuk kelompok usaha produk olahan susu segar di Dusun Boyong, Yogyakarta telah 100\% terlaksana dengan rincian hasil sebagai berikut:

1. Aspek produksi: lay out produksi yang sesuai dengan konsep lean manufacturing, penambahan kapasitas produksi, meningkatnya efisiensi produksi permen susu, bertambahnya varian produk susu yang dapat diproduksi, produk sudah dilengkapi dengan label production dan expired date.

2. Aspek manajemen: peralatan promosi yang relevan, desain produk yang lebih menarik, jaringan pemasaran yang lebih luas, link kerjasama dengan institusi pendidikan (Fakultas Teknologi Pertanian UGM), akun jejaring sosial untuk pemasaran, laporan keuangan sederhana, nota penjualan resmi, mentalitas usaha yang baik, link kerjasama dengan PT Cimory, kemampuan Mitra dalam pengolahan susu meningkat.

\section{Saran}

1. Proses pencairan dana pengabdian masyarakat sebaiknya disesuaikan dengan jadwal pelaksanaan program sehingga tidak mengganggu kelancaran program IbM.

2. Setelah program $\mathrm{lbM}$ berakhir, diperlukan proses pendampingan yang berkelanjutan baik melalui instansi pemerintah maupun swasta.

\section{DAFTAR PUSTAKA}

Firdaus.2005. "Aspek Keadilan Gender Pada Lembaga Kredit Mikro". Kompas, Senin 7 Maret

Rahayu,Ninik S. 2009. "Profil Akses dan Kontrol Perempuan Pelaku Usaha Mikro Terhadap Sumber
Daya Produktif di Kabupaten Bantul, Jurnal Utilitas,(ISSN 0854-76I 0, Vol XVI. No.2 Juli, 2008, FE UMY, Yogyakarta.

Lembaga Penelitian Smeru, 2003. "Peta Upaya Penguatan Usaha Kecil/Mikro di Tingkat Pusat 1997/2003". Diakses Juli,26, 2013 dari www.smeru.or.id 